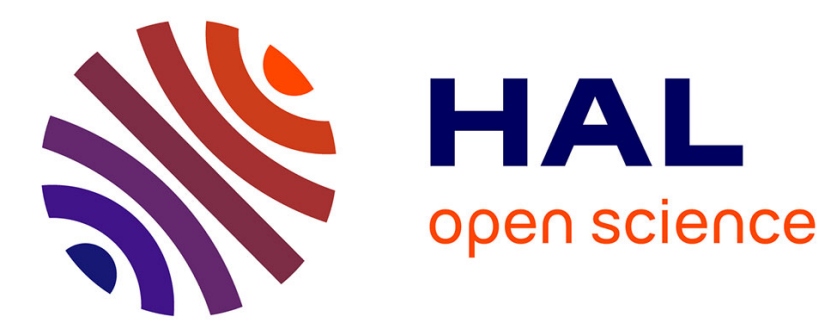

\title{
Formal Aspects of Component Software
}

Gwen Salaün, Anton Wijs

\section{To cite this version:}

Gwen Salaün, Anton Wijs (Dir.). Formal Aspects of Component Software: Proceedings of the 17th International Conference on Formal Aspects of Component Software (FACS 2021). Springer International Publishing, 13077, 2021, Lecture Notes in Computer Science, 10.1007/978-3-030-90636-8 . hal-03507856

\section{HAL Id: hal-03507856 \\ https://hal.inria.fr/hal-03507856}

Submitted on 3 Jan 2022

HAL is a multi-disciplinary open access archive for the deposit and dissemination of scientific research documents, whether they are published or not. The documents may come from teaching and research institutions in France or abroad, or from public or private research centers.
L'archive ouverte pluridisciplinaire HAL, est destinée au dépôt et à la diffusion de documents scientifiques de niveau recherche, publiés ou non, émanant des établissements d'enseignement et de recherche français ou étrangers, des laboratoires publics ou privés. 


\title{
Preface - Proceedings of the 17th International Conference on Formal Aspects of Component Software (FACS'2021)
}

\author{
Gwen Salaün ${ }^{1}$ and Anton Wijs ${ }^{2}$ \\ ${ }^{1}$ Univ. Grenoble Alpes, CNRS, Grenoble INP*, Inria, LIG 38000 Grenoble, France, \\ Gwen.Salaun@univ-grenoble-alpes.fr \\ ${ }^{2}$ Eindhoven University of Technology, 5612 AZ Eindhoven, The Netherlands,
} A.J.Wijs@tue.nl

September 2021

This volume contains the proceedings of the 17th International Conference on Formal Aspects of Component Software (FACS 2021), held online, due to the COVID-19 pandemic, during October $2829,2021$.

Component-based software development proposes sound engineering princi- ples and techniques to cope with the complexity of present-day software sys- tems. However, many challenging conceptual and technological issues remain in component-based software development theory and practice. Furthermore, the advent of service-oriented and cloud computing, cyber-physical systems, and the Internet of Things has brought to the fore new dimensions, such as quality of service and robustness to withstand faults, which require revisiting established concepts and developing new ones.

FACS 2021 was concerned with how formal methods can be applied to component-based software and system development. Formal methods have pro- vided foundations for component-based software through research on mathemati- cal models for components, composition and adaptation, and rigorous approaches to verification, deployment, testing, and certification.

We received 16 submissions for the conference, and all of them were reviewed by three reviewers. Based on their reports and subsequent discussions, the Pro- gram Committee (PC) decided to accept 8 papers ( 7 regular papers and 1 tool paper) for inclusion in this volume and programme of FACS 2021. In addition, we invited Radu Calinescu and Corina Pasareanu to give keynotes. This volume contains an abstract of the talk given by Radu Calinescu and an invited paper by Corina Pasareanu.

We thank Radu Calinescu and Corina Pasareanu for accepting our invitations to give an invited talk, as well as all authors who submitted their work for FACS 2021. We thank the members of the PC for their effort to write timely and high- quality reviews, and their discussions to make the final selection of papers. We also thank the FACS Steering Committee for useful suggestions and support. Finally, we thank the other members of the FACS 2021 organizing committee, Radu Mateescu, Ajay Muroor Nadumane, and Ahang Zuo, for their contribution to organizing the conference.

\footnotetext{
${ }^{*}$ Institute of Engineering Univ. Grenoble Alpes
} 